Short Communication / Klsa Bilimsel Çalışma

\title{
Unable to protect gentamicin-induced nephrotoxicity with allopurinol in rats
}

\author{
Bülent ULUTAŞ ${ }^{1}$, Funda KIRAL ${ }^{2}$, Serap BIRINCIOĞLU ${ }^{3}$ \\ ${ }^{1}$ Department of Internal Medicine, ${ }^{2}$ Biochemistry and ${ }^{3}$ Pathology Faculty of Veterinary Medicine, Adnan Menderes University, \\ Aydin, Turkey .
}

Summary: In this study, it is purposed to investigate the protective effects of allopurinol, a xanthine oxidase inhibitor, against gentamicin -induced nephrotoxicosis. The levels of serum urea, creatinine and plasma MDA were significantly higher and GSH-Px, SOD activities were lower in gentamicin administrated group than the control. The levels of serum urea, creatinine and plasma MDA were significantly higher and GSH-Px, SOD and CAT activities were significantly lower in gentamicin + allopurinol administrated group than the control. Plasma MDA was significantly lower and GSH-Px, SOD activities were higher in gentamicin induced group than gentamicin + allopurinol induced group. In conclusion, results demonstrate that allopurinol, a xanthine oxidase inhibitor, does not prevent the formation of gentamicin induced nephrotoxicosis.

Key words: Allopurinol, gentamicin, nephrotoxicosis, rat.

\section{Ratlarda gentamisine bağlı oluşan nefrotoksisiteden korunmada allopurinolün etkisizliği}

Özet: $\mathrm{Bu}$ çalışmada, ksantin oksidaz inhibitörü olan allopurinolün gentamisin nefrotoksikozisinde koruyucu etkinliğinin araştırılması amaçlanmıştır. Gentamisin verilen grubun serum üre ve kreatinin düzeyleri ile plazma MDA düzeyi kontrol grubuna göre istatistiksel olarak önemli düzeyde yüksek bulunurken, eritrositlerde GSH-Px, SOD aktiviteleri düşük bulundu. Gentamisin+Allopurinol verilen grubun serum üre ve kreatinin düzeyleri ile plazma MDA düzeyi kontrol grubuna göre önemli düzeyde yüksek bulunurken, GSH-Px, SOD ve CAT aktiviteleri önemli düzeyde düşüktü. Gentamisin verilen grubun plazma MDA düzeyi gentamisin+allopurinol verilen gruba göre önemli düzeyde düşük iken GSH-Px, SOD aktiviteleri önemli düzeyde yüksekti. Sonuçta ksantin oksidaz inhibitörü olan allopurinolün gentamisin nefrotoksikozisinin oluşumunu önleyemediği kanısına varılmıştır.

Anahtar sözcükler: Allopurinol, gentamisin, nefrotoksikozis, rat.

Most clinical studies have shown that an aminoglycoside antibiotic gentamicin with potent activity against gram-negative infections induced nephrotoxicity that limits its therapeutic utility (11). The specificity of gentamicin for renal toxicity is apparently related to its preferential accumulation in the renal proximal convoluted tubules, which results in the loss of its brush border integrity (18).

Xantine oxidase (XO) has been implicated as an important source of cytosolic $\mathrm{O}_{2}^{-}(21)$. The potent $\mathrm{XO}$ inhibitor allopurinol and its metabolite oxypurinol are also powerful scavengers of $\mathrm{OH}^{-}$in vitro (4). Allopurinol has a half-life of only $1 \mathrm{~h}$, but it is rapidly converted to oxypurinol which has a half-life of 18-30 h. Like gentamicin, allopurinol and oxypurinol are not bound to serum proteins and are excreted mainly in the urine (6). Therefore, if radical formation is involved in aminoglycoside nephrotoxicity, it seems possible to ameliorate potential gentamicin-induced acute tubular necrosis by concomitant allopurinol administration as an $\mathrm{OH}^{-}$scavenger.

The aim of present study was to examine the protective effect of allopurinol, a xanthine oxidase inhibitor, and the role of free radicals in gentamicininduced nephrotoxicity in rats.

Adult male thirty Wistar rats of weighing 200-250g and having free access to water and standard rat chow were used this experiments. Experiments followed a protocol approved by the Animal Ethics Committee of University of Adnan Menderes. Rats were divided into three groups. Gentamicin was injected subcutaneously to group I (gentamicin) and II (gentamicin+allopurinol) during 10 days at $100 \mathrm{mg} / \mathrm{kg}$ daily. Three days prior to and throughout the period of gentamicin administration, allopurinol was administered orally at $40 \mathrm{mg} / \mathrm{kg}$ daily with the gentamicin injection consecutively to group II. Isotonic saline was injected subcutaneously to group III (control) during 10 days. Only allopurinol administered 
group was not formed because subcutaneously allopurinol at a dose of $50 \mathrm{mg} / \mathrm{kg}$ for 10 days does not have any nephropathic effects (17).

After 24 hours of last dose of gentamicin treatment, blood samples were collected and animals were sacrificed by cervical dislocation under ether anesthesia. For plasma, blood was collected in a heparinized vial and serums in plain vial were separated in a centrifuge for 15 minutes at $1900 \mathrm{~g}$. Serum urea and creatinine levels were determined with commercial kits (Boehringer Manheim, Germany). The lipid peroxidation of plasma was measured by the TBA method as described by Yoshioka et al. (20) Malonyldialdehyde (MDA), formed from the breakdown of polyunsaturated fatty acids, was considered as an index for the peroxidation reaction. The absorbance of the reaction product of MDA with TBA was measured at $532 \mathrm{~nm}$. Quantization was based upon a molar extinction coefficient of $1.56 \times 10^{5} \mathrm{M}^{-1} \mathrm{~cm}^{-1}$.

For erythrocyte separation, heparinized blood was centrifuged at $1700 \mathrm{~g}$ for $10 \mathrm{~min}$ to separate the red blood cells (RBCs) from the plasma. RBCs were washed three times with ice-cold phosphate buffered saline(19). The hemoglobin was determined by Drabkin's method in a $0.1 / \mathrm{ml}$ aliquot of hemolysate (16). Glutathione peroxidase (GSH-px) activity was determined by measuring the rate of oxidation of NADPH at $340 \mathrm{~nm}$ (12). A unit of enzyme activity is expressed as the amount of enzyme needed to oxidize $1 \mathrm{nmol}$ of NADPH oxidized $/ \mathrm{min}$, and the spesific activity is expressed as nmol of NADPH oxidized $/ \mathrm{min} / \mathrm{mgHb}$. Superoxide dismutase activity (SOD) estimation was based on the generation of superoxide radicals produced by xanthine on xantine oxidase, which reacts with 2-(4-iodophenyl)3-(4-nitrophenol)-5-phenyltetrazolium chloride to form a red formazon dye. The SOD activity is then by the degree of inhibition of this reaction. Erythrocyte SOD activity was expressed as $\mathrm{U} / \mathrm{gHb}$ (14). The activity of catalase (CAT) was measured by following the rate $\mathrm{H}_{2} \mathrm{O}_{2}$ decomposition at $240 \mathrm{~nm}$ (9). The enzyme activity is expressed as change in $\mathrm{k} / \mathrm{gHb}$.

The kidneys from all three groups were fixed in $\% 10$ buffered formalin for 24 hours at room temperature. The tissues submitted were prossed trough alcohols and xylene, embedded in paraffin, sectioned at $5 \mu \mathrm{m}$ and stained with hematoxylin and eosin (2).

Reported values are mean \pm SEM $(n=10)$. The significance of differences among three groups was assessed using one way analyses of variance (ANOVA) and for multiple comparison Duncan test was used. The significance was set at $\mathrm{p}<0.05$.

Mean $( \pm$ SEM) for the data obtained in all three groups are given in Table 1 and histopathological findings for all groups illustrated figure 1 .

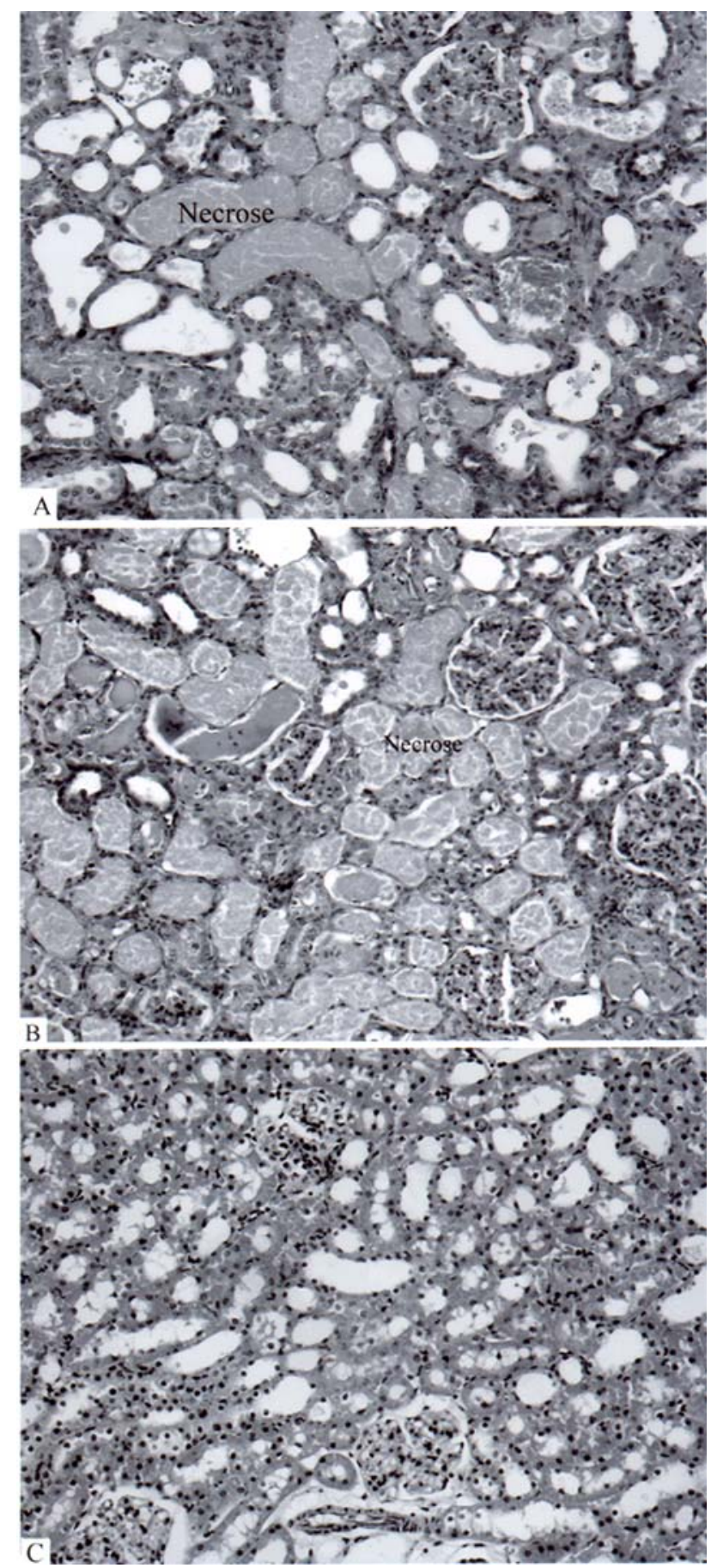

Figure 1: Histopathological view of rats' kidney (x180). A) Gentamicin; B) Gentamicin + allopurinol; C) Control Şekil 1: Rat böbreklerinin histopatolojik görünümü(x180). A) Gentamisin; B) Gentamisin + allopurinol; C) Kontrol

In histopathologic examination, gentamicin (Figure 1/A) and gentamicin+allopurinol (Figure 1/B) treated rats showed acute tubular necrosis of predominantly proximal tubules, but with preservation of tubular basement membranes. In addition to extensive necrosis formation of hyaline casts, dilation of distal tubules was also observed in gentamicin+allopurinol treated rat. In addition to acute tubular necrosis of proximal tubules, formation of hyaline casts, dilatation of distal tubules 
Table 1: Specific enzyme activities in blood and serum urea and creatinine levels between groups. Tablo 1: Gruplar arasında kandaki spesifik enzim aktiviteleri ve serum üre ve kreatinine düzeyleri.

\begin{tabular}{|c|c|c|c|c|c|c|c|}
\hline \multicolumn{2}{|c|}{ Groups } & \multirow{2}{*}{$\begin{array}{c}\begin{array}{c}\text { MDA } \\
(\mu \mathrm{mol} / \mathrm{L})\end{array} \\
35.1 \pm 1.92^{\mathrm{b}}\end{array}$} & \multirow{2}{*}{$\begin{array}{c}\text { GSH-Px } \\
\left(\begin{array}{c}\mathrm{nmol} / \mathrm{NADPH}+\mathrm{H}^{+} / \\
\mathrm{min} / \mathrm{mg}-\mathrm{Hb})\end{array}\right. \\
2989 \pm 143^{\mathrm{b}}\end{array}$} & \multirow{2}{*}{$\begin{array}{c}\begin{array}{c}\text { SOD } \\
(\mathrm{U} / \mathrm{g}-\mathrm{Hb})\end{array} \\
117.7 \pm 4.15^{\mathrm{b}}\end{array}$} & \multirow{2}{*}{$\begin{array}{c}\begin{array}{c}\mathrm{CAT} \\
(\mathrm{k} / \mathrm{g}-\mathrm{Hb})\end{array} \\
14.4 \pm 1.29^{\mathrm{b}}\end{array}$} & \multirow{2}{*}{$\begin{array}{c}\begin{array}{c}\text { Urea } \\
\mathrm{mg} / \mathrm{dl}\end{array} \\
83.3 \pm 7.62^{\mathrm{b}}\end{array}$} & \multirow{2}{*}{$\begin{array}{c}\begin{array}{c}\text { Creatinine } \\
\mathrm{mg} / \mathrm{dl}\end{array} \\
1.73 \pm 0.09^{\mathrm{b}}\end{array}$} \\
\hline 1 & $\mathrm{x} \pm \mathrm{SEM}$ & & & & & & \\
\hline 2 & $\mathrm{x} \pm \mathrm{SEM}$ & $68.3 \pm 2.02^{\mathrm{c}}$ & $2555 \pm 74^{\mathrm{c}}$ & $84.1 \pm 3.97^{\mathrm{c}}$ & $12.7 \pm 0.88^{\mathrm{b}}$ & $103.7 \pm 7.68^{\mathrm{b}}$ & $2.69 \pm 0.08^{\mathrm{c}}$ \\
\hline 3 & $\mathrm{x} \pm \mathrm{SEM}$ & $16.1 \pm 0.67^{\mathrm{a}}$ & $4089 \pm 60.4^{\mathrm{a}}$ & $136.1 \pm 2.76^{\mathrm{a}}$ & $17.6 \pm 1.55^{\mathrm{a}}$ & $41.3 \pm 2.7^{\mathrm{a}}$ & $0.57 \pm 0.03^{\mathrm{a}}$ \\
\hline & $\mathrm{F}$ & $249.108 * * *$ & $63.103^{* * *}$ & $50.746^{* * *}$ & $3.858^{*}$ & $18.218 * * *$ & $168.781^{* * *}$ \\
\hline
\end{tabular}

$* \mathrm{p}<0.05 ; * * \mathrm{p}<0.01 ; * * * \mathrm{p}<0.001$

Group I: gentamicin; Group II: gentamicin + allopurinol; Group III: control

was also observed in gentamicin+allopurinol treated rat. It was noticed an atypical proliferation in epithelial cells of distal and intermediary tubules in gentamicin+ allopurinol treated rats. Control groups did not produce any changes (Figure 1/C).

Free radicals have been implicated in a variety of pathologies and drug toxicity, and reactive oxygen species are implicated in renal ischemia-reperfusion injury (5). Reactive oxygen species produce strand breaks in DNA of renal tissue (13), which in turn is responsible for the activation of poly (ADP-ribose) synthase (15). The result of this study indicate that gentamicin treatment of rats causes accelerated lipid peroxidation in blood as reflected by increased MDA, an end product of lipid peroxidation and by depression of polyunsaturated fatty acids, which serve as substrate for free radical attack. The SOD, CAT and GSH-px activities in erythrocytes were depressed which raises the possibility that impaired removal of free radicals by these antioxidant systems may have contributed to the accelerated lipid peroxidation (10). The accelerated lipid peroxidation and alterations in antioxidant systems were accompanied by functional and histopathological evidence of gentamicin nephrotoxicity. Both depression of glomerular filtration rate and tubular cell injury caused increase in serum creatinine and urea concentration.

The suppressed enzymatic free radical defense system due to diminished activities of the enzymes mentioned might cause exposure of tissues and cells to more peroxidative attacks and damage of the radicals. Accordingly, it has been suggested that some substances with antioxidant capacity might be useful to prevent peroxidation and cellular damage (7). The data indicating that some radical scavengers provide marked functional and histopathological protection against gentamicin toxicity suggest the possibility that the free radical metabolism in the renal tissue is greatly affected by gentamicin (7,8). During the molecular oxygen reintroduced in the tissue is the substrate of superoxide radical formation occurring during the transformation of hypoxantine to xantine by the action of xantine oxidase.
Thus inhibitors of this enzyme, such as allopurinol, have been used scavengers (3). But in this study, it was determined that lipid peroxidation increased however erythrocyte antioxidant capacity decreased more in gentamicin and allopurinol treated group. This could be the reason for increased plasma lipid peroxidation as a cause of the xanthine/xanthine oxidase system which is more likely responsible for the induction of additional damage caused by other systems such as mobilized and activated neutrophils (1). Histopathology of the renal tissues of the rats treated with gentamisin showed tubular necrosis. Similar changes were also reported rats indicating proximal tubular injury $(8,11)$. We have demonstrated that allopurinol did not offer any protection against the development of gentamicin-induced tubular necrosis in the rats as indicated by both renal tubular morphology and tubular function as compared with the groups.

In conclusion, our results demonstrate that free radicals play role in gentamicin-induced nephrotoxicity in rats and allopurinol -a xanthine oxidase inhibitor- does not prevent the formation of nephrotoxicosis.

\section{References}

1. Ciz M, Cizova H, Lojek A, Kubala L, Papezikova I (2001): Ischemia/Reperfusion Injury of Rat Small Intestine: The Effect of Allopurinol Dosage. Transplant P, 33, 2871-2873.

2. Culling CFA, Allison RA, Barr WT (1985): Cellular Pathology Technicgue. Mid-Country Press, London.

3. Diamond JR, Bonventre JV, Karnovsky MJ (1986): A role for oxygen free radicals in aminonucleoside nephrosis. Kidney Int, 29, 478-483.

4. Faure M, Lissi EA, Videla LA (1990): Antioxidant capacity of allopurinol in biological systems. Biochem Int, 21, 357-366.

5. Greene EL, Paller MS (1991): Oxygen free radicals in acute renal failure. Miner Electrolyte Metab, 17, 124-132.

6. Hande K, Reede E, Chabner B (1978): Allopurinol Kinetics. Clin Pharmacol Ther, 23, 598-605.

7. Kavutcu M, Canbolat O, Öztürk S, Olcay E, Ulutepe S, Ekinci C, Gökhun IH, Durak I (1996): Reduced enzymatic antioxidant defence mechanism in kidney tissues 
from gentamicin-treated guine pigs: Effects of vitamin $E$ and C. Nephron, 72, 269-274.

8. Kumar KV, Shifow AA, Naidu MUR, Ratnakar KS (2000): Carvedilol: a beta blocker with antioxidant property protects against gentamicin-induced nephrotoxicity in rats. Life Sci, 66, 2603-2611.

9. Luck H (1965): Catalase. 855-884. In: HU Bergmeyer (Ed.), Methods in Analysis. Academic Press Inc, London.

10. Maestro RF (1980): An approach to free radicals in medicine and biology. Acta Physiol Scand, 492, 153.

11. Maxie MG, Prescott JF. (1993):Urinary System. 487491, In: KVF Jubb, PC Kennedy, N Palmer (Eds), Pathology of Domestic Animals. Academic Press, New York.

12. Paglia DE, Valentine WN (1967): Studies on the quantitative and qualitative characterization of erythrocyte glutathione peroxidase. J Lab Clin Med, 70, 158-169.

13. Richter C (1995): Oxidative damage to mitochondrial DNA and its relationship to ageing. Int $\mathrm{J}$ Biochem Cell Biol, 27, 647-653.

14. Sun Y, Oberley LW, Li Y (1988): A simple for clinical assay of superoxide dismutase. Clin Chem, 34, 497-500.

15. Thiemermann C, Bowes J, Myint FP, Vane JR (1997): Inhibition of the activity of poly(ADP ribose) synthetase reduces ischemia-reperfusion injury in the heart and skeletal muscle. Proc Natl Acad Sci USA, 94, 679-683.

16. Tietz WN (1987): Fundamental of Clinical Chemistry. WB Saunders Co. Philadelphia.
17. Wexler BC, Greenberg BP (1978): Allopurinol-induced myocardial and renal damage in nonarteriosclerotic (virgin) and arteriosclerotic (breeder) Sprague-Dawley rats. Proc Soc Exp Biol Med, 157, 541-549.

18. Whiting PH, Brown PA (1996): The relationship between enzymuria and kidney enzyme activities in experimental gentamicin nephrotoxicity. Ren Fail, 18, 899-909.

19. Winterbourn CC, Hawkins RE, Brain M, Carrel W (1975): The estimation of red cell superoxide dismutase activity. J Lab Clin Med, 55, 337-341.

20. Yoshioka T, Kawoda K, Shimoda T (1979): Lipid peroxidation in maternal and cord blood and protective mechanism against activated-oxygen toxicity in the blood. Am J Obstet. Gynecol, 135, 372-376.

21. Zager RA, Gmur DJ (1989): Effects of xanthine oxidase inhibition on ischemic acute renal failure in the rat. Am J Physiol, 257, 953-958.

Geliş tarihi: 17.11.2004 / Kabul tarihi: 28.06.2005

\author{
Address for correspondance \\ Yrd. Doç.Dr. Bülent Ulutaş \\ Adnan Menderes Üniversitesi, Veteriner Fakültesi

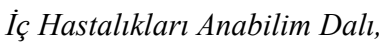 \\ 09016, Işıklı/Aydın-Turkey \\ e-mail: bulutas71@hotmail.com
}

